\title{
An Overview of the Oil Palm Industry: Challenges and Some Emerging Opportunities for Nanotechnology Development
}

\author{
Farhatun Najat Maluin ${ }^{1}\left(\mathbb{D}\right.$, Mohd Zobir Hussein ${ }^{1, *(\mathbb{D})}$ and Abu Seman Idris ${ }^{2}$ \\ 1 Institute of Advanced Technology, Universiti Putra Malaysia, Serdang, Selangor 43400, Malaysia; \\ farhatunnajat@yahoo.com \\ 2 Malaysian Palm Oil Board (MPOB), 6, Persiaran Institusi, Bandar Baru Bangi, Kajang, Selangor 43000, \\ Malaysia; idris@mpob.gov.my \\ * Correspondence: mzobir@upm.edu.my; Tel.: +603-8946-8092
}

Received: 7 January 2020; Accepted: 2 March 2020; Published: 4 March 2020

\begin{abstract}
The increase in the world's oil demand due to the rise of the global population urges more research into the production of sustainable vegetable oilseeds, among which palm oil is the most suitable candidate as it is the most efficient oilseed crop in the world. In an effort to drive the oil palm industry in the areas of food safety and security nanotechnology could offer a sustainable alternative. However, the utilization of nanotechnology in the oil palm industry is still limited. In this review, we aim to encourage the researchers to fully utilize nanotechnology as an alternative solution to tackle the challenges faced by the oil palm industry. Moreover, we also aim to highlight the opportunities for nanotechnology development in oil palm-based related research. The major points are as follows: (1) Nanosensing enables real-time monitoring of plantation status and crop progression, including soil, water and nutrient management, early pest/disease detection, and the spreading of pests/diseases. The use of nanosensing conveniently extends into advanced breeding topics, such as the development of disease-tolerant plants; (2) Nanotechnology could be the answer for the development of integrated management of pest and disease. Active agricultural ingredients can be entrapped or encapsulated into nanocarrier systems to improve their solubility, stability, enhance their efficient delivery to site-specific targets, with longer shelf life, and consequently improved efficacy; (3) Valuable nanomaterials can be isolated and generated from oil palm biomass waste. The utilization of oil palm biomass waste could overcome the issue of the massive production of waste in the oil palm industry and palm oil mills, where oil only accounts for $10 \%$ of the biomass, while $90 \%$ is comprised of the generated biowastes. (4) Palm oil can be utilized as a green alternative as a capping and stabilizing agent in the biosynthesis of metallic and non-metallic nanoparticles. In addition, nanoemulsion formulations using palm oil in drug delivery systems offer advantages such as low toxicity, enhance bioavailability and solubility of the drugs, apart from being inexpensive and environmentally friendly.
\end{abstract}

Keywords: agricultural nanotechnology; oil palm; agronanoparticle; biomass; nanosensor; sustainable agriculture

\section{Introduction}

Oil palm (Elaeis guineensis) is the commodity crop in some countries, especially Malaysia and Indonesia. Indonesia, where oil palm plantations covered by 12.3 million hectares in 2017, is the world's major producer and exporter of palm oil [1]. The second producer, Malaysia, has some 5.85 million hectares of planted oil palm, covering more than $60 \%$ of the agricultural land in 2018 [2]. The other 
producers include Thailand, Colombia, Nigeria, Papua New Guinea, Ecuador, and other countries, which account for 19 million hectares or $0.36 \%$ of the world's agricultural land in total oil palm planted area [3]. It is worth noting that $85 \%$ of the world's palm oil is produced by Indonesia and Malaysia [4]. On the other hand, the world's major consumers and importers of palm oil are India, China, the European Union (EU), the United States (USA), Pakistan, Bangladesh, Nigeria, Philippines, and other countries [3,4].

\section{Oil Palm Industry Challenges}

\subsection{Production and Nutritional Value of Palm Oil}

Elaeis guineensis is an oil palm species that originated from the tropical rainforest of West Africa. The palm tree is monoecious, where the male and female parts can be found on the same tree. It may grow up to more than thirty feet and start to produce fruit bunches from three years of age after planting. Their average productive span-life is about 25 to 30 years, where each tree can bear 8 to 12 fruit bunches per year [5]. Due to their high yield in oil, palm oil is emerging as the most efficient vegetable oilseed crop in the world, whereby a hectare of oil palm plantation can produce ten times more oil compared to the other world-leading oilseed crops, including rapeseed, sunflower, and soybean [4]. The world's primary oilseed production in 2017 are palm oil (68 million tonnes), soybean oil (54 million tonnes), rapeseed oil ( 25 million tonnes), and sunflower oil (19 million tonnes), where the one-third (34\%) of the world's oil and fats production is contributed by palm oil [3].

Palm oil contains a balanced composition of saturated and unsaturated fatty acids with approximately $44 \%$ of monounsaturated oleic acid, $10 \%$ of polyunsaturated linoleic acid, $40 \%$ of saturated palmitic acid, and $5 \%$ of saturated stearic acid. It is free of cholesterol and trans-unsaturated fatty acids. On another note, palm oil is rich in antioxidants in the form of vitamin E (tocopherols and tocotrienols), where 60 to $100 \mathrm{mg}$ of vitamin $\mathrm{E}$ can be found in crude or unrefined palm oil and about half of it remains after refining. Palm oil has the richest tocotrienols content versus other oilseeds such as soybean, sunflower, corn and olive. These tocotrienols have been found effective in lowering bad cholesterol levels as well as protecting the brain against diseases. Palm oil is also rich in vitamin A (carotenoids), where $100 \mathrm{~g}$ of crude oil contains about $50 \mathrm{to} 70 \mathrm{mg}$ of carotenoids. Vitamin A plays an essential role in controlling the growth and functions of body tissues, stimulates the immune system, and promotes good vision [6,7].

\subsection{Current Problems Faced by the Oil Palm Industry}

Pests and diseases currently pose a significant threat to oil palm cultivation. The crop yield can decline severely when infected by pests and diseases that compete with the palm for nutrients and damage the trees. Major pests known in oil palm plantation are defoliators, which include bagworms (Metisa plana and Pteroma pendula), nettle and slug caterpillars (Darna spp. and Setora nitens), moth, rhinoceros beetle, etc. [8]. In Johor Bharu, Malaysia, defoliation by bagworm and Limacodids cause losses in the crops yield over 4 tonnes of fresh fruit bunches (FFB) per acre with $50 \%$ defoliation, at 4 to 6 months after the attack [9]. In another study conducted in Sabah, Malaysia, S. nitens was reported to reduce the production of FFB (27 tonnes per acre) during 30 months with $60 \%$ defoliation [8]. In Indonesia, the yield loss was up to $70 \%$ in the first year after defoliation and can increase up to $90 \%$ in the following year [10]. In an Indian survey from 1995 to 2002, Acria sp. was reported to cause a $29 \%$ yield reduction in the first year, $31 \%$ in the second year, and $21 \%$ in the next consequent year [11]. To suppress these attacks, the application of biopesticides and biological control methods are favored by sustaining the predators and parasitoids as well as pheromone trapping [12-14].

The other problems faced by the oil palm industry is declining oil extraction rate (OER) and the vast production of residue and waste. OER refers to the percentage weight of palm oil generated from the known weight of FFB in the production of palm oil in palm mills. In 2017, average OER in Malaysia declined to $19.7 \%$ compared to the previous year, with $20.2 \%$ [3]. The low quality of FFB, 
as well as climate change, might be contributors to this issue. Apart from that, the oil palm industry and palm oil mills generate about $90 \%$ of biowaste, as oil only accounts for $10 \%$ of the biomass [15]. Improper handling of this residue and biowaste may lead to environmental and health concerns, as it can contribute to eutrophication, pollution, and any other type of disturbances for both aquatic and terrestrial life [16].

\subsection{Basal Stem Rot/Ganoderma Disease}

The major diseases that are prone to attack oil palm trees are vascular wilt, bud and spear rot, sudden wilt, red ring disease and basal stem rot disease. Out of these diseases, the basal stem rot (BSR) disease represents the highest threat to oil palm plantation. The BSR disease, which is also known as Ganoderma disease, is caused by a pathogenic basidiomycete, the white-rot fungus, Ganoderma boninense (G. boninense). High incidence of BSR can be found in Indonesia and Malaysia, whereas Africa, Papua New Guinea, and Thailand show a low incidence of BSR [17]. A study conducted in Malaysia reported that the oil palm planted after coconut trees in the coastal area is more susceptible to this disease. It is reported that $50 \%$ yield losses, with $80 \%$ of the oil palm have been infected in the coastal areas [18]. While in another survey, $30 \%$ of disease incidence of oil palm was observed in both peat and inland soil [19]. In Indonesia, a survey conducted in North Sumatra reported $40 \%$ to $50 \%$ of oil palms were infected after five years of replanting, where the disease may reach up $65 \%$ to $75 \%$ in the next seven years. Meanwhile, a 35\% decline in yield production was observed [20].

\subsection{Ganoderma Symptoms, Mode of Infection and Epidemiology}

Ganoderma disease starts with the colonization of the oil palm root by pathogenic fungi, followed by the degradation of basal stem tissue [21]. The disease then further destroys the internal tissue and the palm xylem, which consequently leads to the disruption of water and nutrient supply from the root to the upper part of the plant [22]. This will cause wilting, desiccated fronds, and unopened spears in the infected trees. At the advanced stage, the basidiocarps or fruiting bodies in the form of a conch shape will develop on the trunk of the palm. At this stage, the fungal infections are already significantly spread throughout the palm, normally resulting in plant death [23]. The fruiting body is then capable of releasing spores and spreading onto the soil or to other palms. Hence, Ganoderma shortens the productive life of oil palms and causes significant yield losses to the oil palm industry [24]. In Malaysia, the estimated yield loss due to this disease can reach up to USD500 million, with an average mortality rate of 3.7\% [25]. Thus, more research on the early detection and treatment of this disease is urgent.

The pathogen can be spread through the root infection and basidiospores $[23,26,27]$. A healthy palm can be infected by root contact with a soil inoculum or other infected palm roots. Thus, it is crucial to eradicate the fungal inoculum in the soil as well as eliminate the infected palm as soon as the disease symptoms got worse. It is reported that 14,000 spores/min can be spread from $10 \mathrm{~cm}^{2}$ of the fruiting body [28]. A study was conducted with a 17 years old palm in North Sumatra, Indonesia. Apart from that, another study showed that the disease could be infected through the wounded surfaces of the palm fronds via spores contact [18].

\subsection{The Current Approach in Ganoderma Disease Management}

Several attempts at the management of Ganoderma disease were conducted, where the infected palm, trunk, and bole, as well as soil contaminated with the Ganoderma inoculum, need to be eliminated to prevent the spread of the disease. Hence, common cultural practices implemented are [29-31]:

- Soil mounding - soil is heaped at the infected palm trunk at $75 \mathrm{~cm}$ height to prevent the weakened bole from being collapsed by the wind [32,33].

- Clean clearing - the remaining fragments within the infected palm area were removed by digging a pit with $1.5 \mathrm{~m}^{2}$ and $60 \mathrm{~cm}$ depth [34]. 
- Sanitation - infected palm and stump were excavated by digging out a large hole $(2 \mathrm{~m} \times 2 \mathrm{~m} \times 1$ $\mathrm{m})$ and then shredded it into smaller pieces [17].

- Digging trenches - the infected palm or stump was isolated by a digging trench with a dimension of $2 \mathrm{~m} \times 2 \mathrm{~m}$ area $(0.5 \mathrm{~m}$ wide and $1 \mathrm{~m}$ depth) to avoid the contact of infected-root and healthy-root [35].

Fungicides remain crucial for the control of pathogenic fungal infections in the field [36,37]. Several fungicides have shown inhibition of $G$. boninense growth (in vitro) with low $\mathrm{EC}_{50}$ values, including hexaconazole ( $\mathrm{EC}_{50}$ of $\left.0.026 \mu \mathrm{g} / \mathrm{mL}\right)$, azoxystrobin $\left(\mathrm{EC}_{50}\right.$ of $\left.0.53 \mu \mathrm{g} / \mathrm{mL}\right)$, carbendazim $\left(\mathrm{EC}_{50}\right.$ of $0.026 \mu \mathrm{g} / \mathrm{mL}$ ), and pyraclostrobin $\left(\mathrm{EC}_{50}\right.$ of $0.25 \mu \mathrm{g} / \mathrm{mL}$ ) [38-40]. In addition, the trunk injection technique was employed in the field studies by applying systemic fungicides, including triademenol, bromuconazole, hexaconazole, and tetraconazole, using a pressure injector [39,41,42]. The findings of the studies show promising results by halting the disease progression in infected palms, hence, prolonging the productive life of the palms. It was reported that $74.4 \%$ of the palms treated with hexaconazole remained alive and produced fruit bunches for up to five more years while none of the untreated palms survived [43,44]. Moreover, dazomet was used as a preventive control by eradicating the Ganoderma inoculum in the infected palm stump, therefore, minimizing the spread of Ganoderma disease within oil palm plantations [45].

Apart from that, biological control offers green alternatives in controlling the Ganoderma disease using bacteria or fungi as biocontrol agents. Endophytic bacteria like Bacillus spp., Serratia spp., Burkholderia spp., and Pseudomonas spp. have shown antimicrobial activity on G. boninense by inducing the plants' systemic resistance against the disease attack [46-49]. Similarly, the antagonistic activity of saprophytic fungi such as Aspergillus spp., Trichoderma spp., and Penicillium spp. on G. boninense has been reported [50,51]. Supplementation of micronutrients such as calcium, copper, manganese, silicon, and boron also has been employed in an effort to enhance the host resistance against pathogen attack [52-55].

\subsection{Oil Palm Industry Value Chain}

The oil palm industry value chain and research and development (R\&D) of oil palm cultivation can be divided into three segments; upstream, midstream, and downstream (Figure 1) [3].

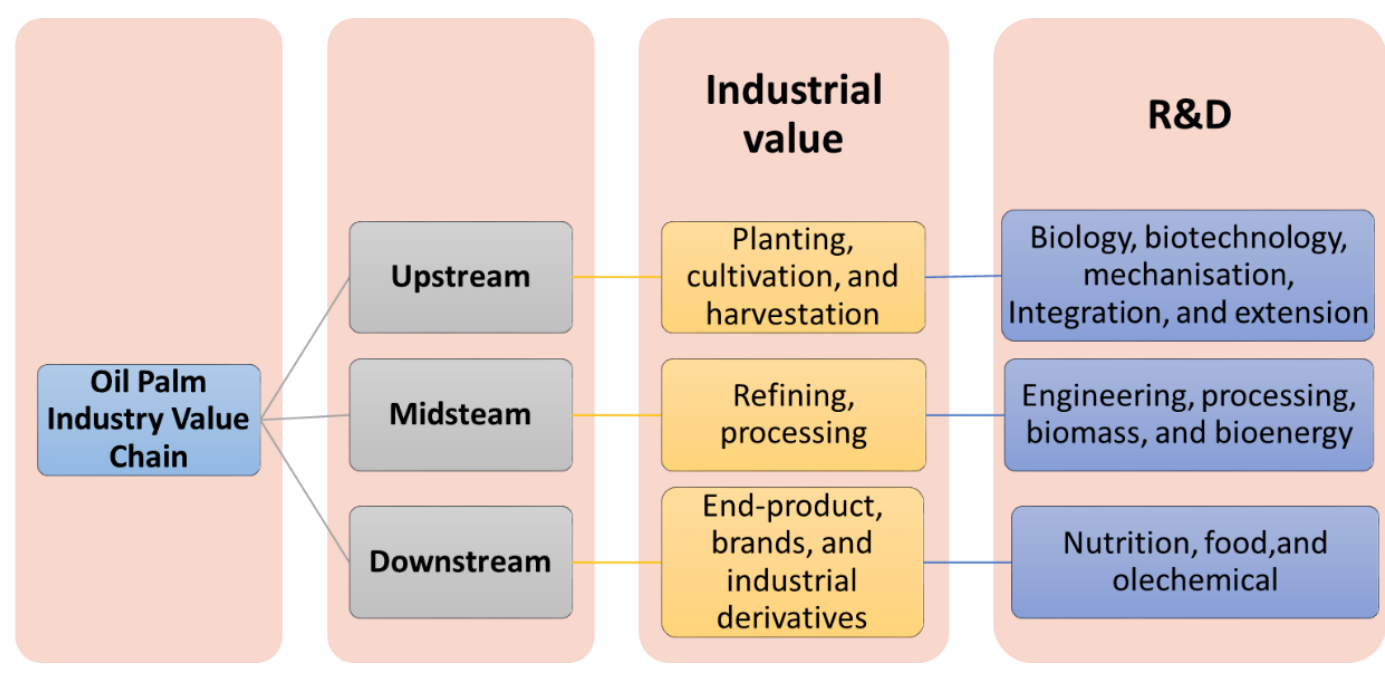

Figure 1. Industrial value chain in oil palm cultivation.

The upstream value chain comprises the planting and cultivation of oil palm, as well as the production of fresh fruit bunches (FFB), crude palm oil (CPO), and crude palm kernel oil (CPKO). The R\&D in the upstream value section is focused on improving the crop yield and controlling pests and diseases in oil palm plantations. It is largely conducted via the integrated management of pests and 
diseases (mainly basal stem rot disease), mechanization and cropping intensification, biotechnology, advanced breeding, and good agricultural practices facilitate in improving the quality and quantity of the crop yields.

The midstream value chain comprises refining, processing, by-products valorization, and biogas production. Much waste is produced in the oil palm industry and palm oil mills, which ranges from oil palm empty fruit bunches (OPEFB), oil palm frond (OPF), oil palm shells (OPS), oil palm mesocarp fiber (OPMF), oil palm trunk (OPT), palm oil fuel ash (POFA), and palm oil mill effluent (POME). Interestingly, this waste can be utilized as sustainable and renewable biomass resources and can be used in biocomposites, paper production, construction board filler, power generation, soil wood, etc.

The downstream value chain comprises the manufacturing end-products of palm oil matrices, palm oil derivatives, and oleochemicals. The yield of palm oil matrices can be divided into two, i.e., crude palm oil (CPO) derived from the fibrous mesocarp of FFB and crude palm kernel oil (CPKO) derived from the palm kernel (the seed enclosed in a shell of the endocarp). The end-products of CPO and CPKO are mainly based on edible uses, including cooking oil, margarine, confectionery, non-dairy creamer, shortening, etc. On the other hand, the derived palm-based oleochemicals, which include fatty acids, fatty alcohols, fatty methyl esters, and glycerin are utilized in cosmetics and personal care industries as raw materials for products such as balms, lipsticks, soaps, detergents, cleaning products, and candles [2]. Besides, CPKO is used in skin-based pharmaceutical products owing to their healing and absorptive properties of tocopherol and tocotrienol [56]. In addition, CPO has been used in biodiesel production by transesterification of triglycerides with alcohol [57].

\section{Nanotechnology Advancements in Agriculture}

Science and technology at the nanoscale refer to the study, understanding and controlled manipulation of the phenomena and structures of any materials that have at one or more dimensions on a scale of 1 to $100 \mathrm{~nm}$. Owing to their large surface-area-to-volume ratio, nanoparticles offer novel and unique properties in both physical and chemical properties, including thermal, mechanical, biological, catalytic activity, electrical conductivity, and optical absorption [58]. The area of nanoscience and nanotechnology R\&D in agriculture cover from uses and applications of nanoparticles, derivation, and generation of nanomaterials from the plant, and nanosensor detection.

In crop science, nanoparticles are generally used as fertilizers, growth stimulators, photosynthesis enhancers, and in the management of pests and diseases [59]. Nanoparticles provide tremendous benefits in agriculture, such as increasing the quality and quantity of crop yields, increasing shelf life, enhanced site-specific distribution, and the absorption of nutrients and active ingredients. It also has low toxicity and helps to reduce the leakage of nutrients and active ingredients, while reducing the environmental pollution. Nanoparticles can function by two different mechanisms, firstly as a stimulant or protective agent, and secondly as a nanocarrier system for existing fertilizers and pesticides.

Figure 2 summarizes the two nanoparticle pathways that have been studied in different plant types. They can be applied directly to plant seeds or through soil drenching (root uptake) or as foliar sprays (leaf uptake). For example, zinc oxide nanoparticles have been widely used as fertilizer to enhance the germination, seedling growth, and biochemical parameters (in cabbage, cauliflower, tomato, etc.). In contrast, their bulk particle is proven to be phytotoxic [60]. Metal nanoparticles, including silver, copper, platinum, gold, sulfur, etc. and chitosan have been intensively studied in vivo and in vitro as bacterial, fungal, and disease inhibitors due to their antiviral, antibacterial, and antifungal properties [59,61]. Silver nanoparticles have been proven to inhibit the growth of a wide range of fungi and bacteria, i.e., Bipolaris sorokiniana [62], Magnaporthe grisea [62], Alternaria alternata [63], Botrytis cinerea [63], etc. Apart from that, chitosan is known for its ability to control or reduce the spread of disease in the plant by inhibiting pathogens and enhancing plant defense mechanisms [63].

The use of nanocarrier systems allows the attachment, absorption, encapsulation, and entrapment of the agriculturally active ingredient to establish efficient nanodelivery system formulations. These nanodelivery systems offer highly efficient controlled release properties for substances like 
fungicides, insecticides, herbicides, etc. that can then more effectively reach the target fungi, insects, and weeds compared to their counterparts. Out of the carrier systems listed in Figure 2, polymer derivatives, chitosan, and silica are the most commonly studied as fungicide nanocarrier systems. In addition, the most researched insecticide nanocarrier systems are chitosan, silica, and lipids. They improve the solubility and stability, reduce volatilization, enhance absorption and site-specific delivery, as well as providing gradual and sustained release. In contrast, the focus of the herbicide nanocarrier systems is to reduce their toxicity level, thus minimizing their negative impacts on the environment [59].

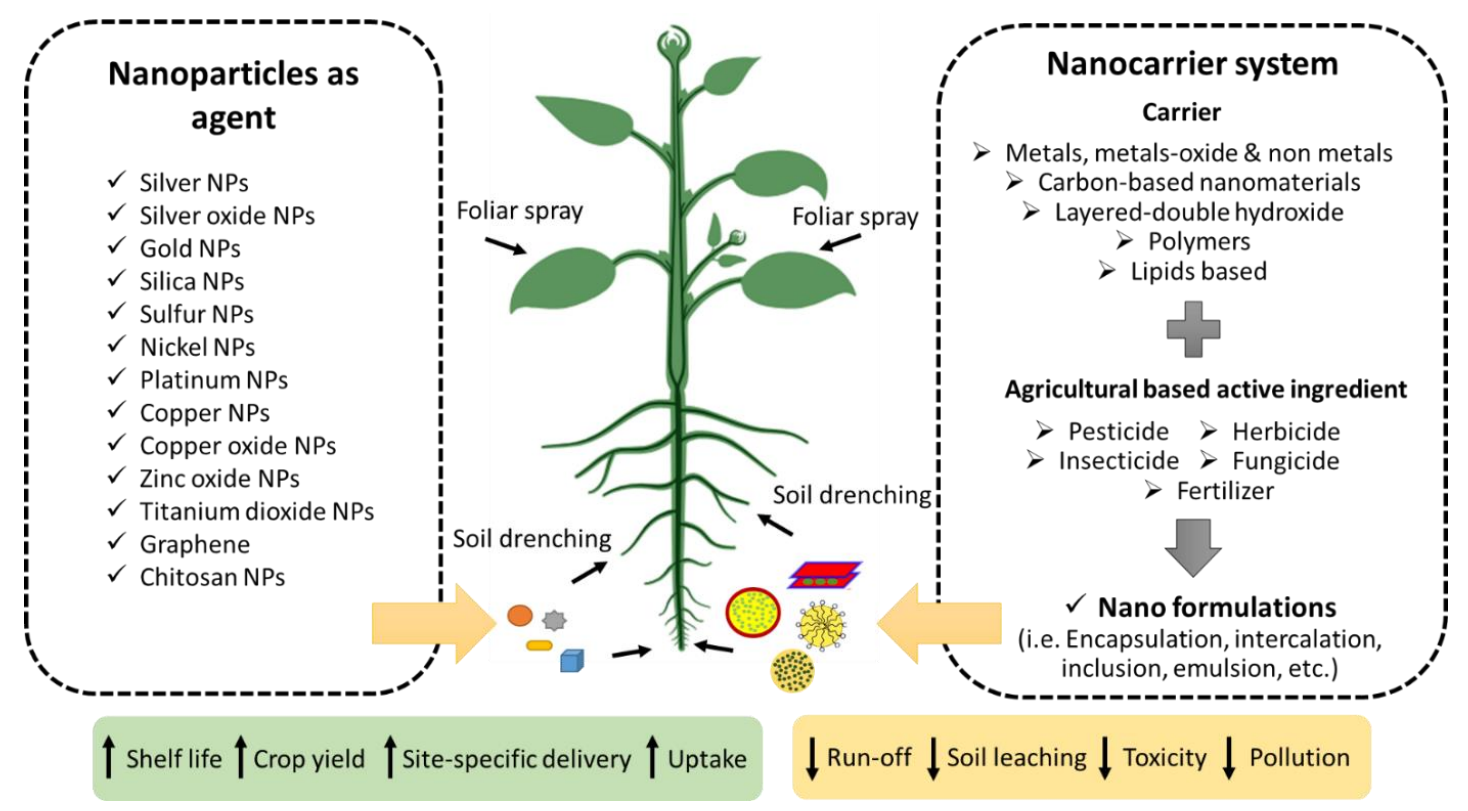

Figure 2. The use of nanoparticles in crop science.

Moreover, plant-derived nanostructures and nanoparticles offer great potential in the preparation of nanomaterials due to their green, inexpensive, eco-friendly, biocompatible, and non-toxic characteristics [64]. Plants can offer a wide range of raw materials, including woods, leaves, roots, stems, and fruits. Plant extracts can be used in the biosynthesis of metal and metal oxide nanoparticles as a capping agent, reducing agent, or stabilizing agent. Various plant metabolites like amino acids, organic acids, polyphenol, flavonoids, alkaloids, terpenoids, and polysaccharides have been reported to play an important role in synthesizing nanoparticles [65].

Apart from that, biomass from plant sources is an excellent alternative in the production of nanocellulose and carbon-based nanomaterials due to their abundance, renewable, inexpensive, green, and non-toxic properties. For example, cellulose nanofibrils and cellulose nanocrystals were successfully extracted from five different types of lignocellulosic plant biomass sources, i.e., pineapple leaf and coir, kapok, sisal, and banana rachis [66]. Moreover, activated carbon was successfully generated from three different types of plant biomass sources, including rice husk, coconut shell, and pine cones using hydrothermal and carbonization treatments [67]. Similarly, graphene was generated from camphor leaves [68], wheat straw [69], spruce bark [70], and bagasse powder [71] via the pyrolysis method.

In addition, nanosensor in agriculture is mainly used for the detection of plant disease and pests as well as monitoring soil conditions, water management, and plant growth hormone [72]. Nanosensors allow real-time monitoring of plantation status and crop development factors, such as soil fertility, moisture contents, temperature, water and nutrient intake, plant disease, and pathogens. The use of nanosensors makes it possible to detect pathogens efficiently in crops and to measure soil conditions (i.e., moisture, $\mathrm{pH}$, nutrient, and pesticide residues). For example, a modified gold electrode with copper nanoparticles was used in the electrochemical sensing of a pathogenic fungus (Sclerotinia 
sclerotiorum) in oilseed rape [73]. Besides, the integration of nanosensors in pesticide residue detection offers several advantages, including high sensitivity and selectivity, fast response time, low detection limit, and compact designs [74].

\section{Recent Nanotechnology Approaches in the Oil Palm Industry}

\subsection{Applications of Nanotechnology in the Oil Palm Industry}

\subsubsection{Palm Oil Lipid-Based Nanoformulation as a Carrier System}

Owing to their high content of fatty acids, CPO and CPKO offer great potential as a carrier system of drugs or nutrients using lipid-based formulations in the form of nanoemulsions (Table 1). Nanoemulsions are formed by the dispersion of droplets of one immiscible liquid into another immiscible liquid. The basic mechanism can be in two conditions; either water-in-oil (W/O) or oil-in-water $(\mathrm{O} / \mathrm{W})$. The utilization of palm oil in the drug nanocarrier and delivery system increased drug biocompatibility, bioavailability and solubility, function as a stabilizing agent, as well as improved drug permeability and shelf life. Besides, the palm oil lipid-based nanoformulation can overcome the issue of high toxicity, poor bioavailability, and poor solubility of several drugs [75]. Palm oil matrices in the form of CPO and CPKO are used as the oil phase in this formulation, and the list of drugs that have been subjected to research is listed in Table 1 .

Table 1. Applications of palm oil matrices as a lipid-based carrier system.

\begin{tabular}{|c|c|c|c|c|c|c|}
\hline $\begin{array}{l}\text { Precursors/ } \\
\text { Starting } \\
\text { Materials }\end{array}$ & $\begin{array}{c}\text { Nanoformulation } \\
\text { of Drug/ } \\
\text { Compound }\end{array}$ & $\begin{array}{c}\text { Emulsion } \\
\text { Size and Its } \\
\text { Type }\end{array}$ & $\begin{array}{c}\text { Zeta Potential and } \\
\text { Stability }\end{array}$ & Surfactants & Applications & Ref. \\
\hline $\begin{array}{l}\text { Crude palm } \\
\text { oil (CPO) }\end{array}$ & $\begin{array}{c}\text { Tocomin }^{\circledR} \\
\text { genistein } \\
\text { nanoemulsion }\end{array}$ & $\begin{array}{l}\text { 173-209 nm; } \\
\mathrm{O} / \mathrm{W}\end{array}$ & $\begin{array}{l}-27 \text { to }-30 \mathrm{mV} \text {; Stable up } \\
\text { to } 3 \text { months at } 4-8{ }^{\circ} \mathrm{C}\end{array}$ & $\begin{array}{l}\text { A mixture of } \\
\text { solutol and } \\
\text { vitamin } \mathrm{E}\end{array}$ & $\begin{array}{l}\text { Pharmaceutical and } \\
\text { skin photoprotection }\end{array}$ & [76] \\
\hline CPO ester & $\begin{array}{l}\text { CPO-tocotrienol- } \\
\text { xanthan gum }\end{array}$ & $\mathrm{O} / \mathrm{W}$ & $\begin{array}{c}\text { Stable sedimentation } \\
\text { rates at earth gravity of } \\
5.2,3.0 \text { and } 2.6 \\
\mathrm{~mm} / \mathrm{month}\end{array}$ & - & Cosmeceuticals & [77] \\
\hline $\begin{array}{l}\text { CPO olein } \\
\text { ester }\end{array}$ & CPO-ibuprofen & $\begin{array}{l}21 \mathrm{~nm} ; \\
\mathrm{O} / \mathrm{W}\end{array}$ & - & $\begin{array}{l}\text { Carbopol } \\
940\end{array}$ & $\begin{array}{l}\text { Anti-inflammatory } \\
\text { and analgesic effect }\end{array}$ & [78] \\
\hline $\begin{array}{l}\text { Crude palm } \\
\text { kernel oil } \\
(\mathrm{CPKO}) \text { ester }\end{array}$ & $\begin{array}{l}\text { CPKO-hydrocolloid } \\
\text { gum- ibuprofen }\end{array}$ & $\begin{array}{l}\text { 16-20 nm; } \\
\text { W/O }\end{array}$ & -14 to $-42 \mathrm{mV}$ & Tween 80 & $\begin{array}{l}\text { Anti-inflammatory } \\
\text { and analgesic effect }\end{array}$ & [79] \\
\hline $\mathrm{CPO}$ & $\begin{array}{l}\text { CPO-hyaluronan- } \\
\text { paclitaxel }\end{array}$ & $\begin{array}{c}263-283 \mathrm{~nm} ; \\
\mathrm{W} / \mathrm{O}\end{array}$ & $\begin{array}{l}-23 \text { to }-34 \mathrm{mV} \text {; stable up } \\
\text { to } 2 \text { months at } 4{ }^{\circ} \mathrm{C} \text { and } \\
2 \text { weeks at } 25^{\circ} \mathrm{C} \text {. }\end{array}$ & Tween 80 & $\begin{array}{l}\text { Ovarian cancer } \\
\text { treatment }\end{array}$ & [80] \\
\hline $\mathrm{CPO}$ olein & CPO-vitamin E & $\begin{array}{l}\text { 20-500 nm; } \\
\text { O/S/W }\end{array}$ & $\begin{array}{l}\text { Stable up to } 1 \text { month at } \\
4,25 \text { and } 40^{\circ} \mathrm{C}\end{array}$ & Brij 30 & Anti-aging agent & [81] \\
\hline CPO ester & CPO-ketoprofen & $\begin{array}{l}230 \mathrm{~nm} ; \\
\mathrm{W} / \mathrm{O}\end{array}$ & - & Tween 80 & $\begin{array}{l}\text { Anti-inflammatory } \\
\text { and analgesic effect }\end{array}$ & [82] \\
\hline CPKO ester & CPKO-docetaxel & $\begin{array}{l}\text { 90-110 nm; } \\
\text { O/W }\end{array}$ & $\begin{array}{c}-30 \text { to }-40 \mathrm{mV} \text {; stable up } \\
\text { to } 3 \text { months at } 5,28 \text { and } \\
45 \pm 1^{\circ} \mathrm{C}\end{array}$ & Tween 80 & Lung cancer treatment & [83] \\
\hline $\mathrm{CPO}$ & $\mathrm{CPO}$-curcumin & $\begin{array}{l}275 \mathrm{~nm} ; \\
\mathrm{O} / \mathrm{W}\end{array}$ & $\begin{array}{l}-36 \mathrm{mV} \text {; stable up to } 1 \\
\text { month at } 25^{\circ} \mathrm{C}\end{array}$ & Tween 80 & $\begin{array}{l}\text { Anti-inflammatory } \\
\text { and anti-cancer }\end{array}$ & [84] \\
\hline $\mathrm{CPO}$ & $\begin{array}{l}\text { CPO-lecithin- } \\
\text { levodopa }\end{array}$ & $110 \mathrm{~nm} ; \mathrm{O} / \mathrm{O}$ & $\begin{array}{l}-31 \mathrm{mV} \text {; stable up to } 6 \\
\text { months at } 4{ }^{\circ} \mathrm{C}\end{array}$ & $\begin{array}{l}\text { Cremaphor } \\
\text { EL }\end{array}$ & Parkinson treatment & [85] \\
\hline CPKO ester & $\begin{array}{c}\text { CPKO-lecithin- } \\
\text { glycerol-aripiprazole }\end{array}$ & $\begin{array}{l}62 \mathrm{~nm} ; \\
\mathrm{O} / \mathrm{O}\end{array}$ & $\begin{array}{l}-32 \mathrm{mV} \text {; stable up to } 9 \\
\text { months at } \pm 5^{\circ} \mathrm{C}\end{array}$ & Tween 80 & $\begin{array}{l}\text { Schizophrenia } \\
\text { treatment }\end{array}$ & [86] \\
\hline CPO ester & $\begin{array}{c}\text { CPO-safflower } \\
\text { seed } \\
\text { oil-chloramphenicol }\end{array}$ & $\begin{array}{l}95 \mathrm{~nm} ; \\
\mathrm{O} / \mathrm{O}\end{array}$ & $-37 \mathrm{mV}$ & Tween 80 & Meningitis treatment & [87] \\
\hline CPKO ester & $\begin{array}{l}\text { CPKO-diclofenac } \\
\text { acid }\end{array}$ & $\begin{array}{l}6 \mathrm{~nm} ; \\
\mathrm{O} / \mathrm{W}\end{array}$ & - & Tween 80 & $\begin{array}{l}\text { Anti-inflammatory } \\
\text { and analgesic effect }\end{array}$ & [88] \\
\hline
\end{tabular}


Tocomin ${ }^{\circledR}$, a red virgin palm oil of ripe palm fruit, with a rich fraction of tocotrienol, is used in nanoemulsion of genistein for enhanced dermal delivery [76]. CPO-tocotrienol nanoemulsion showed high stability, strong dynamic rigidity, and the longest shelf life at a higher oil phase concentration [77]. The nonsteroidal anti-inflammatory drug in the form of lipid nanoemulsion offers great carrier to enhance the absorption and permeation of ibuprofen for topical delivery $[78,79]$. Improved shelf life, sustained released up to six days, and no release burst of paclitaxel was observed in palm oil lipid nanoemulsion, suggesting high efficacy on cancer cells, compared to the commercially available drug [77]. The stability of nanoemulsion can be analyze by observing the physical changes of the liquid formulations including sedimentation, phase separation, creaming, coalescence or flocculation during the tested period [76-88].

\subsubsection{Oil Palm-Based Materials in the Biosynthesis of Nanoparticles}

Oil palm-based material as capping, stabilizing, and reducing agent provides great potential in green and biosynthesis of metal and metal oxide nanoparticles (Table 2). The presence of polar ester bonds and long hydrocarbons in palm oil matrices makes them suitable candidates as stabilizers in the formation of nanoparticles. $\mathrm{CPO}$ and $\mathrm{CPKO}$ have successfully facilitated in the biosynthesis of silver, zinc oxide, and gold nanoparticles [89-92]. Moreover, an OPF offers excellent potential as a precursor in the biosynthesis of silver and gold nanoparticles due to their rich contents of catechins, flavonoids, and polyphenols [93-96]. The suspended solid of fruit in POME, mainly composed of hemicelluloses and lignocelluloses, were proven to help in facilitating the biosynthesis of gold nanoparticle [95].

Table 2. Oil palm-based material helps in facilitating biosynthesis of nanoparticles.

\begin{tabular}{cccc}
\hline Precursors/Starting Materials & Nanoparticles (NPs) & Applications & Ref. \\
\hline CPO & $\mathrm{Ag} \mathrm{NPs}$ & Adsorption and capping agent & {$[92]$} \\
\hline Palm oil mill effluent (POME) & $\mathrm{Au} \mathrm{NPs}$ & $\begin{array}{c}\text { Surfactant, template and } \\
\text { capping agent }\end{array}$ & {$[95]$} \\
\hline $\mathrm{CPO}$ & $\mathrm{ZnO}$ nanostructures & Biotemplates & {$[91]$} \\
\hline $\mathrm{CPO}$ & $\mathrm{CuO} \mathrm{NPs}$ & Glycerolysis of palm oil & {$[90]$} \\
\hline Oil palm frond (OPF) & $\mathrm{Ag} \mathrm{NPs}$ & Reducing and stabilizing agent & {$[93,97]$} \\
\hline CPKO & $\mathrm{Au} \mathrm{NPs}$ & Reducing and stabilizing agent & {$[89]$} \\
\hline OPF & $\mathrm{Au} \mathrm{NPs}$ & Reducing and stabilizing agent & {$[94,96]$} \\
\hline
\end{tabular}

\subsubsection{Other Applications}

In addition, it has been reported that the integration of cerium oxide $\left(\mathrm{CeO}_{2}\right)$ nanoparticles into e palm oil ester and diesel blends could improve the performance and reduce the releases of nitrogen oxide, carbon monoxide, hydrocarbons, and smokes emissions at $10 \%$ exhaust gas recirculation rate [98]. Moreover, due to the high content of tocotrienols in $\mathrm{CPO}$, nanotocotrienols isolated from $\mathrm{CPO}$ have been used in the cosmetics industry. The nanoformulations enable the efficient delivery of tocotrienols through the skin. The formulation is also free of toxic additives, making it ideal for topical applications. In addition, it has been stated that tocotrienol has anti-aging and lipid-lowering properties, apart from its function as vitamin E [99].

\subsection{Generation of Nanomaterials from the Oil Palm Industry}

As discussed earlier, the oil palm industry generates massive amounts of biomass waste, and improper handling of this biowaste may cause serious problems to human health and the environment. One of the solutions is to utilize the biowaste in the production of nanocellulose, carbon-based nanomaterials, nano-silica, and other nano-oil-based palm derivatives that can be used 
in the manufacture of biocomposites, reinforcements and board fillers for building, pollution control, and power generation [100].

The produced oil palm biowaste mainly comes from fruit bunches, fronds, and trunks (Figure 3). First, in the production of palm oil, only the fruit is taken, leaving the oil palm empty fruit bunches (OPEFB) as a waste. Then, $\mathrm{CPO}$ is extracted by pressing the oil from the fruit mesocarp, while CPKO is extracted from the fruit kernels. The process produces oil palm mesocarp fiber (OPMF) and an oil palm kernel shell (OPKS). Besides, POME is a by-product or residue obtained in the production of $\mathrm{CPO}$. Meanwhile, POFA is a residue generated from the combustion of oil palm bunches and palm kernel in palm oil mills. Apart from that, the harvesting of oil palm produced oil palm frond (OPF) and oil palm trunk (OPT) wastes.

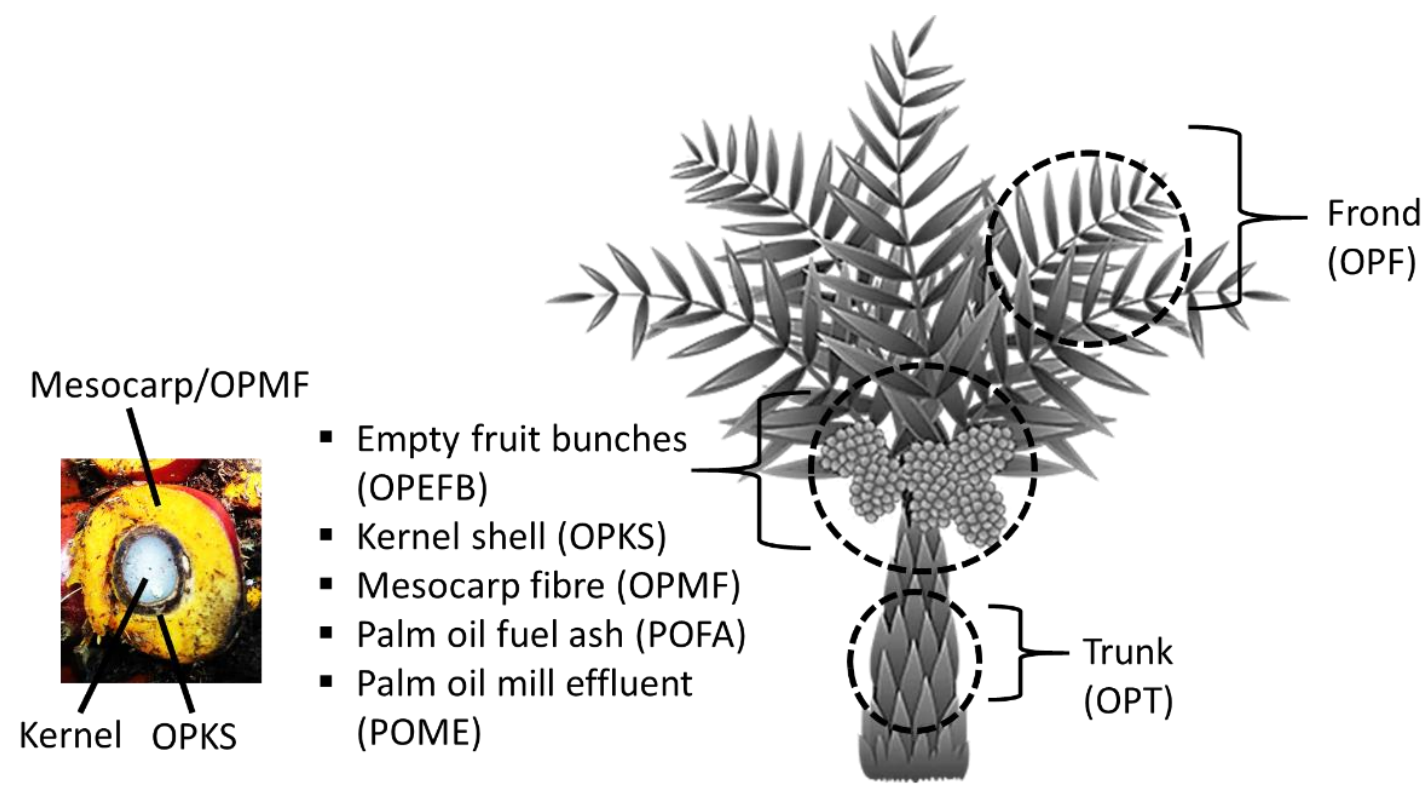

Figure 3. Biowastes generated by the oil palm industry.

\subsubsection{Nanocellulose}

Agricultural biowaste from the oil palm industry offers a great alternative in the production of nanocellulose (NC) and cellulose nanocrystal (CNC) (Table 3). As listed, NC and CNC have successfully been extracted from oil palm biomass, including OPEFB, OPKS, OPMF, OPF, and OPT.

Table 3. Generation of nanomaterials extracted from oil palm biomass waste.

\begin{tabular}{|c|c|c|c|c|}
\hline $\begin{array}{c}\text { Precursors/Starting } \\
\text { Materials }\end{array}$ & $\begin{array}{c}\text { Generation of } \\
\text { Nanomaterials }\end{array}$ & & Applications & Ref. \\
\hline \multirow{5}{*}{$\begin{array}{l}\text { Oil palm empty fruit } \\
\text { bunches } \\
\text { (OPEFB) }\end{array}$} & Nanocellulose & & - & [101-103] \\
\hline & Cellulose nanocrystal & & - & [104-106] \\
\hline & Nano-OPEFB & $\begin{array}{l}\text { 1) } \\
\text { 2) } \\
\text { 3) }\end{array}$ & $\begin{array}{l}\text { Fire retardant nanofiller; } \\
\text { Fabrication on } \\
\text { epoxy nanocomposite } \\
\text { Nanocatalyst in } \\
\text { biodiesel production }\end{array}$ & [107-110] \\
\hline & Carbon nanotubes & 1) & Supercapacitor & [111] \\
\hline & Carbon nanodots & & - & [112] \\
\hline
\end{tabular}


Table 3. Cont

\begin{tabular}{|c|c|c|c|c|}
\hline $\begin{array}{c}\text { Precursors/Starting } \\
\text { Materials }\end{array}$ & $\begin{array}{c}\text { Generation of } \\
\text { Nanomaterials }\end{array}$ & & Applications & Ref. \\
\hline & Activated carbon & 1) & $\begin{array}{l}\text { POME treatment } \\
\text { Supercapacitor }\end{array}$ & {$[111,113]$} \\
\hline & Graphene & 1) & Supercapacitor & {$[111,114]$} \\
\hline & $\begin{array}{l}\text { Graphene oxide; reduced } \\
\text { graphene oxide }\end{array}$ & & - & [115] \\
\hline \multirow{5}{*}{$\begin{array}{l}\text { Oil palm kernel shell } \\
\text { (OPKS) }\end{array}$} & Nanocellulose & & - & [103] \\
\hline & Activated carbon & $\begin{array}{l}\text { 1) } \\
\text { 2) } \\
\text { 3) }\end{array}$ & $\begin{array}{l}\text { POME treatment } \\
\text { Phase change material } \\
\text { Removal of lead }\end{array}$ & {$[113,116,117]$} \\
\hline & $\begin{array}{l}\text { Graphene oxide; reduced } \\
\text { graphene oxide }\end{array}$ & & - & [115] \\
\hline & Carbon nanotubes & & - & [118] \\
\hline & $\begin{array}{l}\text { Defatted OPS } \\
\text { nanoparticles }\end{array}$ & 1) & Filler in biocomposites & [119] \\
\hline \multirow{3}{*}{$\begin{array}{l}\text { Oil palm mesocarp fiber } \\
\text { (OPMF) }\end{array}$} & Nanocellulose & & - & [103] \\
\hline & Cellulose nanocrystal & & - & [120] \\
\hline & Activated carbon & 1) & POME treatment & [113] \\
\hline \multirow{3}{*}{ Oil palm frond (OPF) } & Nanocellulose & 1) & $\begin{array}{l}\text { Fabrication on butyl } \\
\text { butyrate composite }\end{array}$ & [121] \\
\hline & Cellulose nanocrystal & & - & [122] \\
\hline & $\begin{array}{l}\text { Graphene oxide; reduced } \\
\text { graphene oxide }\end{array}$ & & - & [115] \\
\hline $\begin{array}{l}\text { Palm oil mill effluent } \\
\text { (POME) }\end{array}$ & Carbon nanotubes & 1) & Supercapacitor & [111] \\
\hline \multirow{2}{*}{ Oil palm trunk (OPT) } & Nanocellulose & & - & [103] \\
\hline & Cellulose nanocrystal & & - & [123] \\
\hline \multirow{3}{*}{ Palm oil fuel ash (POFA) } & Nano filler & 1) & $\begin{array}{l}\text { Fabrication on } \\
\text { polypropylene composites }\end{array}$ & {$[124,125]$} \\
\hline & Nano silica & & - & [126] \\
\hline & Nano-POFA & 1) & $\begin{array}{l}\text { Biomass mortar } \\
\text { Reinforcement } \\
\text { in concrete }\end{array}$ & [127-129] \\
\hline \multirow{2}{*}{ Waste cooking palm oil } & Graphene & & - & [130] \\
\hline & Carbon nanosphere & & & [131] \\
\hline
\end{tabular}


Their amount of cellulose, holocellulose, hemicellulose, and lignin are tabulated in Table 4 [100, $132,133]$. The extracted cellulose from oil palm biomass was reported to possess high specific strength, low density, excellent thermal properties apart from biodegradable, and inexpensive. The isolated cellulose was subjected to mechanical treatment, chemical treatment, or chemo-mechanical treatment to form NC and CNC.

Table 4. The chemical composition in oil palm biomass.

\begin{tabular}{ccccc}
\hline Oil palm Waste & Cellulose (\%) & Holocellulose (\%) & Hemicellulose (\%) & Lignin (\%) \\
\hline $\begin{array}{c}\text { Oil palm empty fruit } \\
\text { bunches (OPEFB) }\end{array}$ & $43-65$ & $68-86$ & $17-33$ & $13-37$ \\
\hline $\begin{array}{c}\text { Oil palm kernel shell } \\
\text { (OPKS) }\end{array}$ & $27-35$ & $40-47$ & $15-19$ & $48-55$ \\
\hline $\begin{array}{c}\text { Oil palm mesocarp fiber } \\
\text { (OPMF) }\end{array}$ & $43-44$ & $70-71$ & $33-35$ & $22-24$ \\
\hline Oil palm fond (OPF) & $40-50$ & $80-83$ & $34-38$ & $20-21$ \\
\hline Oil palm trunk (OPT) & $29-37$ & $42-45$ & $12-17$ & $18-23$ \\
\hline
\end{tabular}

\subsubsection{Carbon-Based Nanomaterials}

The incorporation of revolutionary carbon-based nanomaterials (CNMs) in various industries, including aerospace, agriculture, drug delivery, and food call for e sustainable alternatives to carbon-rich materials. In line with this, agricultural biomass (henceforth referred to as biowastes) offers a great alternative, since it is cheap, renewable, and eco-friendly. Such biowastes have been commonly used and studied as feedstocks for the preparation of CNMs [134]. Thus, in a country like Indonesia and Malaysia, where the oil palm biomass is abundant, the oil palm biomass offers a great alternative in the production of CNMs. As listed in Table 3, CNMs in the form of carbon nanotubes, carbon nanodots, carbon nanospheres, activated carbon, graphene layer, graphene oxide, and reduced graphene oxide have been successfully generated from OPEFB, OPKS, OPMF, OPF, POME, and waste cooking oil via various types of processes, including pyrolysis, chemical vapor deposition, and carbonization.

\subsubsection{Other Nanomaterials}

In addition, POFA offers a great alternative in nano-silica production due to its high amount of silica content. Nano silica has successfully isolated from POFA via sulfuric acid leaching, followed by alkali treatment (Table 3) [89].

Natural nanofillers have been successfully extracted from OPEFB, OPKS, and POFA (Table 3). The use of natural nanofillers as bio-filters and reinforcement materials in composites offers a wide range of applications, including construction, pharmaceutical, and food industries, due to their biodegradable, renewable, affordable, low density, and good specific strength [135].

\subsection{Nanosensor and Detection in Oil Palm Plantation}

To the best of our knowledge, nanosensors in oil palm plantations are mainly used for the detection of G. boninense, a pathogenic fungus that leads to basal stem rot (BSR) disease. As discussed earlier, BSR disease is the most severe threatening disease in oil palm plantation and cultivation. However, the research work in this field is limited but blooming. Early detection is crucial, as the symptoms of infection usually show only at the advanced stage of the disease, where there is no treatment for it [136]. Optical and electrochemical nanosensors were employed in the detection of G. boninense (Table 5). Akanbi et al. and Fowotade et al. employed electrochemical sensing of secondary metabolites secreted by oil palm seedlings infected by G. boninense. The sensing method was tested on 14 and 30 days of the healthy and infected root of oil palm germinated seedlings. The results were to discriminate between the healthy and infected root; thus, showing potential as disease screening in the field $[136,137]$. 
Other work had also been conducted by extracting the DNA of the infected seedlings. Hushiarian et al. reported that the detection could be performed using magnetic nanoparticles as immobilized DNA via amide linkages $[138,139]$. Meanwhile, Dutse et al. worked on ruthenium complexes as redox indicators and helped in the intercalation of DNA $[140,141]$.

Table 5. Nanosensors used in the detection of basal stem rot/Ganoderma disease in oil palms.

\begin{tabular}{ccccc}
\hline $\begin{array}{c}\text { Type of } \\
\text { Nanosensor }\end{array}$ & Analyte & Modified Electrode & LOD & Ref. \\
\hline Electrochemical & $\begin{array}{c}\text { Secondary } \\
\text { metabolite } \\
\text { (quinoline) }\end{array}$ & $\begin{array}{c}\text { AUNPs-aMWCNTs/ } \\
\text { CTSNPs-aMWCNTs/SPCE }\end{array}$ & $3.75 \times 10^{-9} \mathrm{M}$ & {$[137]$} \\
\hline Electrochemical & $\begin{array}{c}\text { Secondary } \\
\text { metabolites }\end{array}$ & $\begin{array}{c}\text { Bilayer of } \\
\text { [AUNPs-aMWCNTs/ } \\
\text { CTSNPs-aMWCNTs]/SPCE }\end{array}$ & $0.01657-0.007793 \mu \mathrm{g} / \mathrm{mL}$ & {$[136]$} \\
\hline Electrochemical & DNA & AuE/PEDOT-PSS/AuNps & $1.59 \times 10^{-17} \mathrm{M}$ & {$[139]$} \\
\hline Electrochemical & DNA & PEDOT-PSS/AgNPs/AuE & $5.00-6.20 \times 10^{-16} \mathrm{M}$ & {$[140$,} \\
\hline Optical & DNA & CdSe/ZnS quantum dots & - & {$[138]$} \\
\hline
\end{tabular}

The Nanostring ${ }^{\circledR}$ nCounter has been adopted as a fast and easy screening of oil palm tolerance towards G. boninense. The tool detects the oil palm tolerant genes via genomic and transcriptomics exploration. Previously, the identification of G. boninense oil palm tolerance was conducted via nursery studies of artificially inoculated G. boninense to the oil palm seedling, which requires tedious work and also time-consuming. Othman et al. reported that the tool showed potential in differentiating potential susceptible palm from potential tolerant palm; thus, further assessment is required in order to develop biomarkers in the breeding of G. boninense oil palm tolerant [24].

\subsection{Agronanochemicals in Oil Palm Cultivation}

The incorporation of agronanochemicals in oil palm plantation and cultivation is mainly based on the management and control of BSR disease. Similar to nanosensors, the research work in this field has just commenced and is minimal. The disease assessments were evaluated by in vitro antifungal efficacy of agronanochemicals on G. boninense. However, no work on the in vivo evaluation using agronanochemicals in the management of BSR disease has been reported. A fungicide nanodelivery system employed by Mustafa et al. was made by intercalating fungicide in the zinc/aluminum layered-double hydroxide (Zn-Al-LDH) via the ion exchange method [142,143]. The fungicides used are hexaconazole and dazomet, which have been previously proven to be effective against G. boninense [39,144], and resulted in H-Zn-Al-LDH and D-Zn-Al-LDH, respectively. Controlled release properties of hexaconazole were achieved in $\mathrm{H}-\mathrm{Zn}-\mathrm{Al}-\mathrm{LDH}$, and the $\mathrm{EC}_{50}$ value obtained was $30.0 \pm 2.9 \mathrm{ng} / \mathrm{mL}$. On the other hand, phytotoxicity studies on H-Zn-Al-LDH and D-Zn-Al-LDH were conducted on oil palm seedlings, and the findings showed that both were able to lower the phytotoxic effect compared to their counterpart. Meanwhile, earlier work done by our group encapsulated the same fungicide (hexaconazole and/or dazomet) into chitosan nanoparticles in the formation of an effective fungicide nanodelivery system. The three formulated systems are chitosan-hexaconazole nanoparticles (CHEN) [145], chitosan-dazomet nanoparticles (CDEN) [146], and chitosan-hexaconazole-dazomet nanoparticles (CHDEN) [147]. The work established that the particle size in all the three systems can be tuned by varying the concentration of the crosslinking agent of sodium tripolyphosphate (TPP). Moreover, it has been established that smaller particle size results in a higher antifungal activity on G. boninense. A synergistic effect of dual loaded of fungicides in CHDEN as an antifungal agent also can be observed. The lowest $\mathrm{EC}_{50}$ value achieved for $\mathrm{CHDEN}$ is $3.5 \pm 1.0 \mathrm{ng} / \mathrm{mL}$, while the lowest $\mathrm{EC}_{50}$ value achieved for $\mathrm{CHEN}$ and $\mathrm{CDEN}$ are $4.6 \pm 1.6$ and $13.7 \pm 1.8 \mathrm{ng} / \mathrm{mL}$, respectively. 
In addition, biological control using Trichoderma nanoemulsion was conducted by Azhari et al. The percentage inhibition recorded was $84.49 \%$, however, the concentration used is not mentioned [148]. Lee et al. reported that the antifungal efficacy of phenazine nanoemulsion on G. boninense with $70.74 \%$ percentage inhibition was achieved at $1000 \mu \mathrm{g} / \mathrm{mL}$ [149]. Apart from that, Shepros ${ }^{\circledR}$ introduced a product called Ganoderma eliminator, which is based on the nano-colloidal antifungal agent. Its ingredients include nanosilver, Nano Alpha 10, food additives, as well as plant derivatives. The product is reported able to penetrate through unreachable areas such as fungal septa and able to inhibit the ergosterol production in the fungal cell membrane.

\section{Future Research Directions}

The oil palm industry should explore and use nanotechnology for holistic management and beneficiation of the industry, which includes down, middle and upstream industries. Real-time monitoring by nano-sensing technology and controlled release formulation of fertilizers and fungicides could overcome the labor shortage, increase the oil extraction rate and reduce the losses due to the diseases and pests in oil palm cultivation. Nano-enabled agrochemicals can enhance the crop yield and health while simultaneously lower the toxicity of agrochemicals as well as minimizing the runoff and leaching of agrochemicals that can cause health and environmental concerns. The utilization of oil palm biomass to generate various carbon nanomaterials and nanocellulose, especially from the downstream oil palm industry is the way forward towards the "zero-waste" green and environmentally friendly oil palm industry.

\section{Conclusions}

Nanotechnology could be the solution to the problems faced by the oil palm industry and palm oil mills. Nanotechnology can be utilized in every aspect ranging from plantation, cultivation, production, and waste handling. Nanosensing could revolutionize oil palm cultivation through the real-time monitoring of the crop status, including crop health and growth, the supplementation of water and nutrient, and the occurrences and spread of pests and diseases. The rise of BSR disease in oil palm plantations with no available cure yet urges more research. Active pesticide agents can be loaded into nanocarrier capsules (i.e., polymers, lipids, carbon-based materials, and metals) to give low toxicity and effective pesticide nanodelivery systems which offer a sustainable alternative to conventional pesticides, hence driving the safety and security of the oil palm industry. Moreover, the oil palm biomass wastes can be exploited as sustainable and renewable resources, which can subsequently be converted into valuable products. The increase of the world's oil demand due to the increase in population urges more research in improving the crop yields and oleochemicals, hence driving the industry in the production of sustainable palm oil.

Author Contributions: Writing original draft preparation, F.N.M.; writing-review and editing, M.Z.H., A.S.I.; supervision, M.Z.H., A.S.I.; funding acquisition, M.Z.H., A.S.I. All authors have read and agreed to the published version of the manuscript.

Funding: This work was supported by the Ministry of Education of Malaysia under the LRGS-NanoMITe program, vote no. 9443100 and 5526300, and Universiti Putra Malaysia under GP-IPS vote no. 9647400. F.N.M. would like to thanks UPM for graduate research fellowship (GRF) and Sime Darby Foundation for the scholarship.

Conflicts of Interest: The authors declare no conflict of interest.

\section{Abbreviations}

FFB: fresh fruit bunches; OER: oil rate extraction; BSR: basal stem rot; OPEFB: oil palm empty fruit bunches; OPF: oil palm frond; OPS: oil palm shells; OPKS: oil palm kernel shell; OPMF: oil palm mesocarp fiber; OPT: oil palm trunk; POFA: palm oil fuel ash; POME: palm oil mill effluent; CPO: crude palm oil; CPKO: crude palm kernel oil; W/O: water-in-oil; O/W: oil-in-water; O/S/W: oil-in-surfactant-in-water; O/O: oil-in-oil; NPs: nanoparticles; NC: nanocellulose; CNC: cellulose nanocrystal; CNMs: carbon-based nanomaterials; aMWCNTs: activated multi-walled carbon nanotubes; AUNPs: gold nanoparticles; CTSNPs: chitosan nanoparticles; SPCE: screen-printed carbon electrode; AuE: gold electrode; PEDOT-PSS: poly(3,4-ethylenedioxythiophene) poly(styrenesulfonate); AgNPs: silver nanoparticles; LOD: limit of detection. 


\section{References}

1. Sigit, W.; Demetria, D.H.; Yanuar, A.; Widya, K.Z.; Eko, P.; Asep, U.; Susilo, N.D.; Erni, M. Tree Crop Estate Statistic of Indonesis 2015-2017: Oil Palm; Directorate General of Estate Crops: Jakarta, Indonesia, 2016.

2. Oil Palm Planted Area 2018. Available online: http://bepi.mpob.gov.my/index.php/en/statistics/area/189area-2018/857-oil-palm-planted-area-as-at-dec-2018.html (accessed on 1 December 2018).

3. Kushairi, A.; Loh, S.K.; Azman, I.; Hishamuddin, E.; Ong-Abdullah, M.; Izuddin, Z.; Razmah, G.; Sundram, S.; Parveez, G.K.A. Oil palm economic performance in Malaysia and R\&D progress in 2017. J. Oil Palm Res. 2018, 30, 163-195.

4. Darby, S. Palm oil facts and figures. Sime Darby Plantation: Profile and Fact Sheets; Sime Darby: Kuala Lumpur, Malaysia, 2014; pp. 1-8.

5. Barcelos, E.; Rios, S.d.A.; Cunha, R.N.; Lopes, R.; Motoike, S.Y.; Babiychuk, E.; Skirycz, A.; Kushnir, S. Oil palm natural diversity and the potential for yield improvement. Front. Plant. Sci. 2015, 6, 190. [CrossRef] [PubMed]

6. Wahid, M.B.; Abdullah, S.N.A.; IE, H. Oil Palm. Plant. Prod. Sci. 2005, 8, 288-297. [CrossRef]

7. Nagendran, B.; Unnithan, U.; Choo, Y.; Sundram, K. Characteristics of red palm oil, a carotene-and vitamin E-rich refined oil for food uses. Food Nutr. Bull. 2000, 21, 189-194. [CrossRef]

8. Kalidas, P. Pest problems of oil palm and management strategies for sustainability. Agrotech. 2012, 1, 11.

9. Wood, B.; Corley, R.; Goh, K. Studies on the effect of pest damage on oil palm yield. In Proceedings of the International Oil Palm Conference, Kuala Lumpur, Malaysia, 16-18 November 1973; pp. 360-377.

10. Desmier De Chenon, R.; Hasibuan, H.; Ps, S.; Purba, R.Y. Importance of food plants for parasitoids in the control of nettle caterpillars and bagworms in oil palm plantations. In Proceedings of the International Oil Palm Conference, Bali, Indonesia, 12 July 2002; pp. 520-528.

11. Kalidas, P. Stress management in insect pests on oil palm, Elaeis guineensis Jacq. J. Oilseeds Res. 2004, 21, 220-223.

12. Mazmira, M.; Ramlah, S.; Najib, M.; Norman, K.; Kushairi, A.; Wahid, M.B. Pest management of bagworm in southern perak by aerial spraying with Bacillus thuringiensis. Oil Palm Bulletin 2011, 63, 24-33.

13. Mohamad, S.A.; Masijan, Z.; Moslim, R.; Rosman, M.; Ali, A.; Ahmad, S.N. Biological agents and insecticides to control bunch moth, Tirathaba rufivena in oil palm estates in Sarawak, Malaysia. J. Oil Palm Res. 2017, 29, 323-332. [CrossRef]

14. Harjotedjo, S.; Sahari, B.; Palgoenadi, B. Management of oil palm pests and diseases in Indonesia: learning from the past, adapting for the future. In Proceedings of the 5th MPOB-IOPRI International seminar, Kuala Lumpur, Malaysia, 2-23 November 2013; p. A21.

15. Abdullah, N.; Sulaiman, F. The oil palm wastes in Malaysia. In Biomass Now-Sustainable Growth and Use; IntechOpen: Rijeka, Croatia, 2013.

16. Loehr, R. Agricultural waste management: problems, processes, and approaches; Elsevier: Ithaca, NY, USA, 2012.

17. Idris, A.; Kushairi, A.; Ismail, S.; Ariffin, D. Selection for partial resistance in oil palm progenies to Ganoderma basal stem rot. J. Oil Palm Res. 2004, 16, 12-18.

18. Lim, T.; Chung, G.; Ko, W. Basal stem rot of oil palm caused by Ganoderma boninense. J. Plant. Pathol. 1992, 1, 147-152.

19. Rao, V.; Lim, C.; Chia, C.; Teo, K. Studies on Ganoderma spread and control. Planter 2003, 79, 367-383.

20. Subagio, A.; Foster, H. Implications of Ganoderma disease on loss in stand and yield production of oil palm in North Sumatra. In Proceedings of the MAPPS Conference, Kuala Lumpur, Malaysia, 18-20 August 2003.

21. Durand-Gasselin, T.; Asmady, H.; Flori, A.; Jacquemard, J.C.; Hayun, Z.; Breton, F.; De Franqueville, H. Possible sources of genetic resistance in oil palm (Elaeis guineensis Jacq.) to basal stem rot caused by Ganoderma boninense-prospects for future breeding. Mycopathologia 2005, 159, 93-100. [CrossRef] [PubMed]

22. Sahebi, M.; Hanafi, M.M.; Wong, M.-Y.; Idris, A.; Azizi, P.; Jahromi, M.F.; Shokryazdan, P.; Abiri, R.; Mohidin, H. Towards immunity of oil palm against Ganoderma fungus infection. Acta Physiol. Plant. 2015, 37, 195. [CrossRef]

23. Cooper, R.M.; Flood, J.; Rees, R. Ganoderma boninense in oil palm plantations: current thinking on epidemiology, resistance and pathology. Planter 2011, 87, 515-526. 
24. Othman, N.Q.; Paravamsivam, P.; Tan, J.S.; Lee, Y.P.; Kwan, Y.; Alwee, S.S.R.S. Validation of differential gene expression of transcriptome assembly via Nanostring ${ }^{\circledR}$ technologies analysis platform. J. Oil Palm Res. 2018, 30, 36-46. [CrossRef]

25. Hushiarian, R.; Yusof, N.A.; Dutse, S.W. Detection and control of Ganoderma boninense: strategies and perspectives. SpringerPlus 2013, 2, 555. [CrossRef]

26. Sanderson, F. An insight into spore dispersal of Ganoderma boninense on oil palm. Mycopathologia 2005, 159, 139-141. [CrossRef]

27. Rees, R.; Flood, J.; Hasan, Y.; Potter, U.; Cooper, R.M. Basal stem rot of oil palm (Elaeis guineensis); mode of root infection and lower stem invasion by Ganoderma boninense. Plant. pathology 2009, 58, 982-989. [CrossRef]

28. Rees, R.; Flood, J.; Hasan, Y.; Wills, M.A.; Cooper, R.M. Ganoderma boninense basidiospores in oil palm plantations: evaluation of their possible role in stem rots of Elaeis guineensis. Plant. Pathol. 2012, 61, 567-578. [CrossRef]

29. Rees, R.W. Ganoderma stem rot of oil palm (Elaeis guineensis): mode of infection, epidemiology and biological control; University of Bath: Bath, UK, 2006.

30. Ariffin, D.; Idris, A.; Singh, G. Status of Ganoderma in oil palm. Ganoderma diseases of perennial crops 2000, 49-68.

31. Chong, K.P.; Dayou, J.; Alexander, A. Detection and control of Ganoderma boninense in oil palm crop; Springer: Berlin, Germany, 2017.

32. Ho, C.; Khairuddin, H. Usefulness of soil mounding treatments in prolonging productivity of prime-aged Ganoderma infected palms. Planter 1997, 73, 239-244.

33. Hashim, A. Ganoderma versus Mycorrhiza. Oil Palm Bulletin 2003, 6-14.

34. Flood, J.; Bridge, P.; Holderness, M. Ganoderma diseases of perennial crops; CABI: Wallingford, UK, 2000.

35. Lim, K.; Udin, W. Management of Ganoderma in peat soil in Indonesia. In Proceedings of the Second International Seminar on Oil Palm Diseases: Advances in Ganoderma Research and Management, Yogyakarta, Indonesia, 31 May 2010.

36. Petit, A.-N.; Fontaine, F.; Vatsa, P.; Clément, C.; Vaillant-Gaveau, N. Fungicide impacts on photosynthesis in crop plants. Photosynth. Res. 2012, 111, 315-326. [CrossRef] [PubMed]

37. Langsdorf, G. Handbook of Agriculture; Yuste, M.P., Gostincar, J., Eds.; MarcelDekker, Inc.: New York, NY, USA, 1999; p. 768.

38. Ramasamy, S. Cross-infectivity and decay ability of Ganoderma species parasitic to rubber, oil palm and tea. Ganoderma diseases of perennial crops; CABI Publishing: Oxon, UK, 2000.

39. Idris, A.; Arifurrahman, R.; Kushairi, A. Hexaconale as a preventive treatment for managing Ganoderma in oil palm. МРОВ TS Info. Ser. 2010, 75.

40. Said, N.; Omar, D.; Nasehi, A.; Wong, M.Y. Pyraclostrobin suppressed Ganoderma basal stem rot (BSR), promoted plant growth and induced early expression of beta-1, 3-glucanase in oil palm (Elaeis guineensis). J. Oil Palm Res. 2019, 31, 248-261.

41. Chung, G. Preliminary results on trunk injection of fungicides against Ganoderma basal stem rot in oil palm. In Proceedings of the Ganoderma workshop, Bangi, Selangor, Malaysia, 11 September 1990; pp. 81-97.

42. Lim, T.; Hamm, R.; Mohamad, R. Persistency and volatile behaviour of selected chemicals in treated soil against three basidiomycetous root disease pathogens. Int. J. Pest. Manag. 1990, 36, 23-26. [CrossRef]

43. Idris, A.; Ahmad, H.; Ariffin, D.; Ismail, S. Prolonging the productive life of Ganoderma-infected palms with hexaconazole. MPOB TS Info. Ser. 2004.

44. Idris, A.; Arifurrahman, R.; Kushairi, D. An evaluation of hexaconazole for controlling Ganoderma basal stem rot of oil palm in the field as a preventive treatment. In Proceedings of the PIPOC (Agriculture, Biotechnology and Sustainability), Kuala Lumpur, Malaysia, 24-25 July 2009.

45. Idris, A.; Maizatul, S. Stump treatment with dazomet for controlling Ganoderma disease in oil palm. MPOB TS Info. Ser. 2012, 107.

46. Buana, R.F.N.; Wahyudi, A.T.; Mathius, N. Control activity of potential antifungal-producing Burkholderia sp. in suppressing Ganoderma boninense growth in oil palm. Asian J. Agric. Res. 2014, 8, 259-268. [CrossRef]

47. Ramli, N.R.; Mohamed, M.S.; Seman, I.; Zairun, M.A.; Mohamad, M. The potential of endophytic bacteria as a biological control agent for Ganoderma disease in oil palm. Sains Malays. 2016, 45, 401-409. 
48. Sundram, S.; Meon, S.; Seman, I.A.; Othman, R. Application of Arbuscular mycorrhizal fungi with Pseudomonas aeruginosa UPMP3 reduces the development of Ganoderma basal stem rot disease in oil palm seedlings. Mycorrhiza 2015, 25, 387-397. [CrossRef] [PubMed]

49. Azizah, S.N.; Mubarik, N.R.; Sudirman, L.I. Potential of chitinolytic Bacillus amyloliquefaciens SAHA 12.07 and Serratia marcescens KAHN 15.12 as biocontrol agents of Ganoderma boninense. Res. J. Microbiol. 2015, 10, $452-465$.

50. Alexander, A.; Phin, C.K. Combination of biological agents in suppressing colonization of Ganoderma boninense of basal stem rot. Am.-Eurasian J. Sustain. Agric. 2014, 8, 1-7.

51. Sundram, S.; Abdullah, F.; Ahmad, Z.A.M.; Yusuf, U.K. Efficacy of single and mixed treatments of Trichoderma harzianum as biocontrol agents of Ganoderma basal stem rot in oil palm. J. Oil Palm Res. 2008, 20, 470-483.

52. Najihah, N.I.; Hanafi, M.M.; Idris, A.S.; Hakim, M.A. Silicon treatment in oil palms confers resistance to basal stem rot disease caused by Ganoderma boninense. Crop. Prot. 2015, 67, 151-159. [CrossRef]

53. Bivi, M.S.H.R.; Paiko, A.S.; Khairulmazmi, A.; Akhtar, M.; Idris, A.S. Control of basal stem rot disease in oil palm by supplementation of calcium, copper, and salicylic acid. Plant. Pathol. J. 2016, 32, 396. [CrossRef] [PubMed]

54. Fabien, F.T.; Hanafi, M.M.; Idris, A.; Kadir, J.; Jamaludin, N.; Mohidin, H.; Syed, R.S.O. Effect of micronutrients-enriched fertilizers on basal stem rot disease incidence and severity on oil palm (Elaeis guineensis Jacq.) seedlings. Am. J. Appl. Sci. 2014, 11, 1841-1859.

55. Nur Sabrina, A.; Sariah, M.; Zaharah, A. Suppression of basal stem rot disease progress in oil palm (Elaeis guineensis) after copper and calcium supplementation. Pertanika J. Trop. 2012, 35.

56. Singh, I.; Nair, R.S.; Gan, S.; Cheong, V.; Morris, A. An evaluation of crude palm oil (CPO) and tocotrienol rich fraction (TRF) of palm oil as percutaneous permeation enhancers using full-thickness human skin. Pharm. Dev. Technol. 2018, 1-7. [CrossRef]

57. Mekhilef, S.; Siga, S.; Saidur, R. A review on palm oil biodiesel as a source of renewable fuel. Renew. Sust. Energy Rev. 2011, 15, 1937-1949. [CrossRef]

58. Roco, M.C. Nanoparticles and nanotechnology research. J. Nanopart. Res. 1999, 1, 1-6. [CrossRef]

59. Worrall, E.; Hamid, A.; Mody, K.; Mitter, N.; Pappu, H. Nanotechnology for plant disease management. Agronomy 2018, 8, 285. [CrossRef]

60. Singh, N.; Amist, N.; Yadav, K.; Singh, D.; Pandey, J.; Singh, S. Zinc oxide nanoparticles as fertilizer for the germination, growth and metabolism of vegetable crops. J. Nanoeng. Nanomanuf. 2013, 3, 353-364. [CrossRef]

61. Elmer, W.; White, J.C. The future of nanotechnology in plant pathology. Annu. Rev. Phytopathol. 2018, 56, 111-133. [CrossRef] [PubMed]

62. Jo, Y.K.; Kim, B.H.; Jung, G. Antifungal activity of silver ions and nanoparticles on phytopathogenic fungi. Plant. Dis. 2009, 93, 1037-1043. [CrossRef] [PubMed]

63. Ouda, S.M. Antifungal activity of silver and copper nanoparticles on two plant pathogens, Alternaria alternata and Botrytis cinerea. Res. J. Microbiol. 2014, 9, 34-42. [CrossRef]

64. Mohammadinejad, R.; Karimi, S.; Iravani, S.; Varma, R.S. Plant-derived nanostructures: types and applications. Green Chem. 2016, 18, 20-52. [CrossRef]

65. Singh, P.; Kim, Y.J.; Zhang, D.; Yang, D.C. Biological synthesis of nanoparticles from plants and microorganisms. Trends Biotechnol. 2016, 34, 588-599. [CrossRef]

66. Deepa, B.; Abraham, E.; Cordeiro, N.; Mozetic, M.; Mathew, A.P.; Oksman, K.; Faria, M.; Thomas, S.; Pothan, L.A. Utilization of various lignocellulosic biomass for the production of nanocellulose: a comparative study. Cellulose 2015, 22, 1075-1090. [CrossRef]

67. Momodu, D.; Okafor, C.; Manyala, N.; Bello, A.; ZebazeKana, M.G.; Ntsoenzok, E. Transformation of plant biomass waste into resourceful activated carbon nanostructures for mixed-assembly type electrochemical capacitors. Waste Biomass Valori. 2017, 1-13. [CrossRef]

68. Shams, S.S.; Zhang, L.S.; Hu, R.; Zhang, R.; Zhu, J. Synthesis of graphene from biomass: a green chemistry approach. Mater. Lett. 2015, 161, 476-479. [CrossRef]

69. Chen, F.; Yang, J.; Bai, T.; Long, B.; Zhou, X. Facile synthesis of few-layer graphene from biomass waste and its application in lithium ion batteries. J. Electroanal. Chem. 2016, 768, 18-26. [CrossRef]

70. Sun, Z.; Zheng, M.; Hu, H.; Dong, H.; Liang, Y.; Xiao, Y.; Lei, B.; Liu, Y. From biomass wastes to vertically aligned graphene nanosheet arrays: A catalyst-free synthetic strategy towards high-quality graphene for electrochemical energy storage. Chem. Eng. J. 2018, 336, 550-561. [CrossRef] 
71. Mahmoudian, L.; Rashidi, A.; Dehghani, H.; Rahighi, R. Single-step scalable synthesis of three-dimensional highly porous graphene with favorable methane adsorption. Chem. Eng. J. 2016, 304, 784-792. [CrossRef]

72. Kaushal, M.; Wani, S.P. Nanosensors: frontiers in precision agriculture. In Nanotechnology; Springer: Singapore, 2017; pp. 279-291.

73. Wang, Z.; Wei, F.; Liu, S.Y.; Xu, Q.; Huang, J.Y.; Dong, X.Y.; Yu, J.H.; Yang, Q.; Zhao, Y.D.; Chen, H. Electrocatalytic oxidation of phytohormone salicylic acid at copper nanoparticles-modified gold electrode and its detection in oilseed rape infected with fungal pathogen Sclerotinia sclerotiorum. Talanta 2010, 80, 1277-1281. [CrossRef] [PubMed]

74. Liu, Y.; Tong, Z.; Prud'homme, R.K. Stabilized polymeric nanoparticles for controlled and efficient release of bifenthrin. Pest. Manag. Sci. 2008, 64, 808-812. [CrossRef]

75. Efendy Goon, D.; Kadir, S.A.; Hamimah, S.; Latip, N.A.; Mazlan, M. Palm oil in lipid-based formulations and drug delivery systems. Biomolecules 2019, 9, 64. [CrossRef]

76. Brownlow, B.; Nagaraj, V.J.; Nayel, A.; Joshi, M.; Elbayoumi, T. Development and in vitro evaluation of vitamin E-enriched nanoemulsion vehicles loaded with genistein for chemoprevention against UVB-induced skin damage. J. Pharm. Sci. 2015, 104, 3510-3523. [CrossRef]

77. Ng, S.H.; Woi, P.M.; Basri, M.; Ismail, Z. Characterization of structural stability of palm oil esters-based nanocosmeceuticals loaded with tocotrienol. J. Nanobiotechnology 2013, 11, 27.

78. Abdullah, G.Z.; Abdulkarim, M.F.; Salman, I.M.; Ameer, O.Z.; Yam, M.F.; Mutee, A.F.; Chitneni, M.; Mahdi, E.S.; Basri, M.; Sattar, M.A. In vitro permeation and in vivo anti-inflammatory and analgesic properties of nanoscaled emulsions containing ibuprofen for topical delivery. Int. J. Nanomedicine 2011, 6, 387. [CrossRef]

79. Salim, N.; Basri, M.; Rahman, M.B.; Abdullah, D.K.; Basri, H. Modification of palm kernel oil esters nanoemulsions with hydrocolloid gum for enhanced topical delivery of ibuprofen. Int. J. Nanomedicine 2012, 7, 4739. [PubMed]

80. Abu-Fayyad, A.; Kamal, M.M.; Carroll, J.L.; Dragoi, A.-M.; Cody, R.; Cardelli, J.; Nazzal, S. Development and in-vitro characterization of nanoemulsions loaded with paclitaxel $/ \gamma$-tocotrienol lipid conjugates. Int. J. Pharm. 2018, 536, 146-157. [CrossRef] [PubMed]

81. Ramli, S.; Norhman, N.; Zainuddin, N.; Ja'afar, S.M.; Rahman, I.A. Nanoemulsion based palm olein as vitamin E carrier. Malays. J. Analytical Sci. 2017, 21, 1399-1408.

82. Sakeena, M.H.F. Anti-inflammatory and analgesic effects of ketoprofen in palm oil esters nanoemulsion. J. Oleo Sci. 2010, 59, 667-671.

83. Asmawi, A.A.; Salim, N.; Ngan, C.L.; Ahmad, H.; Abdulmalek, E.; Masarudin, M.J.; Abdul Rahman, M.B. Excipient selection and aerodynamic characterization of nebulized lipid-based nanoemulsion loaded with docetaxel for lung cancer treatment. Drug Deliv. Transl. Res. 2018, 1-12. [CrossRef]

84. Raviadaran, R.; Chandran, D.; Shin, L.H.; Manickam, S. Optimization of palm oil in water nano-emulsion with curcumin using microfluidizer and response surface methodology. LWT-Food Sci. Technol. 2018, 96, 58-65. [CrossRef]

85. Zainol, S.; Basri, M.; Basri, H.B.; Shamsuddin, A.F.; Abdul-Gani, S.S.; Karjiban, R.A.; Abdul-Malek, E. Formulation optimization of a palm-based nanoemulsion system containing levodopa. Int. J. Mol. Sci. 2012, 13, 13049-13064. [CrossRef]

86. Masoumi, H.R.F.; Basri, M.; Samiun, W.S.; Izadiyan, Z.; Lim, C.J. Enhancement of encapsulation efficiency of nanoemulsion-containing aripiprazole for the treatment of schizophrenia using mixture experimental design. Int. J. Nanomedicine 2015, 10, 6469. [CrossRef]

87. Musa, S.H.; Basri, M.; Masoumi, H.R.F.; Karjiban, R.A.; Malek, E.A.; Basri, H.; Shamsuddin, A.F. Formulation optimization of palm kernel oil esters nanoemulsion-loaded with chloramphenicol suitable for meningitis treatment. Colloids Surf. B Biointerfaces 2013, 112, 113-119. [CrossRef]

88. Abedi Karjiban, R.; Basri, M.; Abdul Rahman, M.B.; Salleh, A.B. Molecular dynamics simulation of palmitate ester self-assembly with diclofenac. Int. J. Mol. Sci. 2012, 13, 9572-9583. [CrossRef]

89. Irfan, M.; Ahmad, T.; Moniruzzaman, M.; Abdullah, B. Effect of pH on ionic liquid mediated synthesis of gold nanoparticle using Elaise guineensis (palm oil) kernel extract. IOP Conf. Ser. Mater. Sci. Eng. 2017, 204, 012002. [CrossRef]

90. Ong, H.R.; Khan, M.M.R.; Ramli, R.; Yunus, R.M.; Rahman, M.W. Glycerolysis of palm oil using copper oxide nanoparticles combined with homogeneous base catalyst. New J. Chem. 2016, 40, 8704-8709. [CrossRef] 
91. Ramimoghadam, D.; Hussein, M.Z.B.; Taufiq-Yap, Y.H. Synthesis and characterization of ZnO nanostructures using palm olein as biotemplate. Chem. Cent. J. 2013, 7, 71. [CrossRef] [PubMed]

92. Zamiri, R.; Zakaria, A.; Ahangar, H.A.; Sadrolhosseini, A.R.; Mahdi, M.A. Fabrication of silver nanoparticles dispersed in palm oil using laser ablation. Int. J. Mol. Sci. 2010, 11, 4764-4770. [CrossRef] [PubMed]

93. Ahmad, T.; Irfan, M.; Bhattacharjee, S. Parametric study on gold nanoparticle synthesis using aqueous Elaise guineensis (oil palm) leaf extract: effect of precursor concentration. Procedia. Engineering 2016, 148, 1396-1401. [CrossRef]

94. Ahmad, T.; Bustam, M.; Irfan, M.; Moniruzzaman, M.; Asghar, H.; Bhattacharjee, S. Effect of volume of gold chloroauric acid on size, shape and stability of biosynthesized AuNPs using aqueous Elaeis guineensis (oil palm) leaves extract. Int. J. Automot. Mech. Eng. 2018, 15. [CrossRef]

95. Gan, P.P.; Ng, S.H.; Huang, Y.; Li, S.F.Y. Green synthesis of gold nanoparticles using palm oil mill effluent (POME): a low-cost and eco-friendly viable approach. Bioresour. Technol. 2012, 113, 132-135. [CrossRef]

96. Usman, A.I.; Aziz, A.A.; Noqta, O.A. Bio-synthesis of triangular and hexagonal gold nanoparticles using palm oil fronds' extracts at room temperature. Mater. Res. Express 2018, 5, 015042. [CrossRef]

97. Ramli, N.A.; Jai, J.; Mohd Yusof, N.; Zamanhuri, N.A. Green synthesis of silver nanoparticles using Elaeis guineensis from palm leaves: influence of $\mathrm{pH}$ in reaction kinetic. Adv. Mat. Res. 2015, 1113, 560-565. [CrossRef]

98. Ganesan, S.; Munuswamy, D.; Appavu, P.; Arunkumar, T.; Devaraja, Y. Effect of EGR \& nanoparticles on performance and emission characteristics of a diesel engine fuelled with palm biodiesel and diesel blends. J. Oil Palm Res. 2019, 31, 130-137.

99. Hasan, Z.A.A.; Idris, Z.; Gani, S.; Basri, M. In vitro safety evaluation of palm tocotrienol-rich fraction nanoemulsions for topical application. J. Oil Palm Res. 2018, 30, 150-162.

100. Dungani, R.; Aditiawati, P.; Aprilia, S.; Yuniarti, K.; Karliati, T.; Suwandhi, I.; Sumardi, I. Biomaterial from Oil Palm Waste: Properties, Characterization and Applications. In Palm Oil; IntechOpen: London, UK, 2018.

101. Lani, N.; Ngadi, N.; Johari, A.; Jusoh, M. Isolation, characterization, and application of nanocellulose from oil palm empty fruit bunch fiber as nanocomposites. J. Nanomater. 2014, 2014, 13. [CrossRef]

102. Gea, S.; Panindia, N.; Piliang, A.; Sembiring, A.; Hutapea, Y. All-cellulose composite isolated from oil palm empty fruit bunch. J. Phys. Conf. Ser. 2018, 1116, 042013. [CrossRef]

103. Okahisa, Y.; Furukawa, Y.; Ishimoto, K.; Narita, C.; Intharapichai, K.; Ohara, H. Comparison of cellulose nanofiber properties produced from different parts of the oil palm tree. Carbohyd. Polym. 2018, 198, 313-319. [CrossRef]

104. Nazir, M.S.; Wahjoedi, B.A.; Yussof, A.W.; Abdullah, M.A. Eco-friendly extraction and characterization of cellulose from oil palm empty fruit bunches. BioResources 2013, 8, 2161-2172. [CrossRef]

105. Al-Dulaimi, A.A.; Wanrosli, W. Isolation and characterization of nanocrystalline cellulose from totally chlorine free oil palm empty fruit bunch pulp. J. Polym. Environ. 2017, 25, 192-202. [CrossRef]

106. Wibowo, A.; Madani, H.; Judawisastra, H.; Restiawaty, E.; Lazarus, C.; Budhi, Y.W. An eco-friendly preparation of cellulose nano crystals from oil palm empty fruit bunches. IOP Conf. Ser. Earth Environ. Sci. 2018, 105, 012059. [CrossRef]

107. Saba, N.; Paridah, T.M.; Abdan, K.; Ibrahim, N.A. Preparation and characterization of fire retardant nano-filler from oil palm empty fruit bunch fibers. BioResources 2015, 10, 4530-4543. [CrossRef]

108. Saba, N.; Tahir, P.M.; Abdan, K.; Ibrahim, N.A. Fabrication of epoxy nanocomposites from oil palm nano filler: mechanical and morphological properties. BioResources 2016, 11, 7721-7736. [CrossRef]

109. Saba, N.; Jawaid, M.; Alothman, O.Y.; Almutairi, Z. Evaluation of dynamic properties of nano oil palm empty fruit bunch filler/epoxy composites. J. Mater. Res. Technol. 2018, 8, 1470-1475. [CrossRef]

110. Husin, H.; Asnawi, T.; Firdaus, A.; Husaini, H.; Ibrahim, I.; Hasfita, F. Solid catalyst nanoparticles derived from oil-palm empty fruit bunches (OP-EFB) as a renewable catalyst for biodiesel production. IOP Conf. Ser. Mater. Sci. Eng. 2018, 1, 012008. [CrossRef]

111. Hendriansyah, R.; Devianto, H.; Prakoso, T.; Widiatmoko, P.; Nurdin, I.; Srimurti, S.; Kusuma, K.R. Nano carbon materials from palm oil wastes for supercapacitor applications. In Proceedings of the 20174 th International Conference on Electric Vehicular Technology (ICEVT), Bali, Indonesia, 2-5 October 2017; pp. 13-18.

112. Gea, S.; Muis, Y.; Novita, T.; Piliang, A.F. Synthesis of carbon nanodots from cellulose nanocrystals oil palm empty fruit by pyrolysis method. J. Phys. Conf. 2018, 1120, 012071. 
113. Wafti, N.; Lau, H.L.N.; Loh, S.K.; Aziz, A.A.; Ab Rahman, Z.; May, C.Y. Activated carbon from oil palm biomass as potential adsorbent for palm oil mill effluent treatment. J. Oil Palm Res. 2017, 29, 278-290. [CrossRef]

114. Tahir, N.A.M.; Abdollah, M.F.B.; Tamaldin, N.; Amiruddin, H.; Tokoroyama, T.; Umehara, N. Potential of growing graphene from solid waste products. In Proceedings of the SAKURA Symposium on Mechanical Science and Engineering, Centre for Advanced Research on Energy, Nagoya, Japan, 8-10 November 2017; pp. 26-28.

115. Nasir, S.; Hussein, M.; Yusof, N.; Zainal, Z. Oil palm waste-based precursors as a renewable and economical carbon sources for the preparation of reduced graphene oxide from graphene oxide. Nanomaterials 2017, 7 , 182. [CrossRef]

116. Nicholas, A.; Hussein, M.; Zainal, Z.; Khadiran, T. Palm Kernel Shell Activated Carbon as an Inorganic Framework for Shape-Stabilized Phase Change Material. Nanomaterials 2018, 8, 689. [CrossRef]

117. Al Mamun, A.; Ahmed, Y.M.; Ma'an Fahmi, R.A.; Jameel, A.T.; AlSaadi, M.A. The optimum condition for the synthesis of carbon nanofibers on activated carbon to remove lead from aqueous solution. Int. J. Nanoelectron. Mater. 2019, 12, 135-144.

118. Al Mamun, A.; AlSaadi, M.A.; Alam, M.Z.; Sopyan, I. Carbon nanotubes grown on oil palm shell powdered activated carbon as less hazardous and cheap substrate. Appl. Nanosci. 2018, 8, 1767-1779. [CrossRef]

119. Dungani, R.; Fizree, H. Production and characterization of the defatted oil palm shell nanoparticles. Sains Malays. 2016, 45, 833-839.

120. Chieng, B.; Lee, S.; Ibrahim, N.; Then, Y.; Loo, Y. Isolation and characterization of cellulose nanocrystals from oil palm mesocarp fiber. Polymers 2017, 9, 355. [CrossRef]

121. Razib, M.F.M.; Wahab, R.A. Statistical optimization of Candida rugosa lipase supported on chitosan/nanocellulose composite for efficient synthesis of butyl butyrate. eProceed. Chem. 2018, 3.

122. Nordin, N.A.; Sulaiman, O.; Hashim, R.; Kassim, M.H.M. Oil palm frond waste for the production of cellulose nanocrystals. J. Phys. Sci. 2017, 28, 115-126. [CrossRef]

123. Mazlita, Y.; Lee, H.; Hamid, S. Preparation of cellulose nanocrystals bio-polymer from agro-industrial wastes: Separation and characterization. Polym. Polym. Compos. 2016, 24, 719-728. [CrossRef]

124. Bhat, A.H.; Khalil, H.A. Exploring "nano filler" based on oil palm ash in polypropylene composites. BioResources 2011, 6, 1288-1297.

125. Khalil, H.A.; Mahayuni, A.R.; Rudi, D.; Almulali, M.; Abdullah, C. Characterization of various organic waste nanofillers obtained from oil palm ash. BioResources 2012, 7, 5771-5780. [CrossRef]

126. Khan, M.I.; Azizli, K.; Sufian, S.; Man, Z.; Khan, A.S. Simultaneous preparation of nano silica and iron oxide from palm oil fuel ash and thermokinetics of template removal. Rsc Adv. 2015, 5, 20788-20799. [CrossRef]

127. Lim, N.H.A.S.; Samadi, M.; Hussin, M.W.; Sam, A.R.M.; Ariffin, N.F.; Ismail, M.A.; Lee, H.S.; Ariffin, M.A.M. Influence of oil palm biomass waste on compressive strength and chloride penetration of mortar. MATEC Web Conf. 2017, 138, 01008. [CrossRef]

128. Hamada, H.M.; Jokhio, G.A.; Yahaya, F.M.; Humada, A.M. Applications of Nano palm oil fuel ash and Nano fly ash in concrete. IOP Conf. Ser. Mater. Sci. Eng. 2018, 342, 012068. [CrossRef]

129. Tang, W.; Lee, H.-S.; Vimonsatit, V.; Htut, T.; Singh, J.; Wan Hassan, W.; Ismail, M.; Seikh, A.; Alharthi, N. Optimization of micro and nano palm oil fuel ash to determine the carbonation resistance of the concrete in accelerated condition. Materials 2019, 12,130. [CrossRef]

130. Robaiah, M.; Rusop, M.; Abdullah, S.; Khusaimi, Z.; Azhan, H.; Asli, N.A. Synthesis graphene layer at different waste cooking palm oil temperatures. AIP Conf. Proc. 2017, 1877, 030008.

131. Arie, A.A.; Hadisaputra, L.; Susanti, R.F.; Devianto, H.; Halim, M.; Enggar, R.; Lee, J. Synthesis of carbon nano materials originated from waste cooking oil using a nebulized spray pyrolysis. J. Phys. Conf. 2017, 877, 012020. [CrossRef]

132. Astimar, A.A.; Kumudeswar, D.; Mohamad, H.; Anis, M. Effects of physical and chemical pre-treatments on xylose and glucose production from oil palm press fibre. J. Oil Palm Res. 2002, 14, 10-17.

133. Yasim-Anuar, T.A.T.; Ariffin, H.; Norrahim, M.N.F.; Hassan, M.A. Factors affecting spinnability of oil palm mesocarp fiber cellulose solution for the production of microfiber. BioResources 2016, 12, 715-734. [CrossRef]

134. Wang, Z.; Shen, D.; Wu, C.; Gu, S. State-of-the-art on the production and application of carbon nanomaterials from biomass. Green Chem. 2018, 20, 5031-5057. [CrossRef] 
135. Saba, N.; Tahir, P.; Jawaid, M. A review on potentiality of nano filler/natural fiber filled polymer hybrid composites. Polymers 2014, 6, 2247-2273. [CrossRef]

136. Fowotade, S.A.; Yusof, N.A.; Abdullah, J.; Sulaiman, Y.; Rahman, S.F.A. Enhanced electrochemical sensing of secondary metabolites in oil palms for early detection of Ganoderma boninense based on novel nanoparticle-chitosan functionalized multi-walled carbon nanotube platform. Sens. Biosensing Res. 2019, 100274. [CrossRef]

137. Akanbi, F.; Yusof, N.; Abdullah, J.; Sulaiman, Y.; Hushiarian, R. Detection of quinoline in G. boninense-infected plants using functionalized multi-walled carbon nanotubes: A field study. Sensors 2017, 17, 1538. [CrossRef]

138. Hushiarian, R.; Yusof, N.; Abdullah, A.; Ahmad, S.; Dutse, S. A novel DNA nanosensor based on CdSe/ZnS quantum dots and synthesized $\mathrm{Fe}_{3} \mathrm{O}_{4}$ magnetic nanoparticles. Molecules 2014, 19, 4355-4368. [CrossRef]

139. Hushiarian, R.; Yusof, N.A.; Abdullah, A.H.; Ahmad, S.A.A.; Dutse, S.W. Facilitating the indirect detection of genomic DNA in an electrochemical DNA biosensor using magnetic nanoparticles and DNA ligase. Anal. Chem. Res. 2015, 6, 17-25. [CrossRef]

140. Dutse, S.W.; Yusof, N.A.; Ahmad, H.; Hussein, M.Z.; Hushiarian, R. DNA-based biosensor for detection of Ganoderma boninense, an oil palm pathogen utilizing newly synthesized ruthenium complex [Ru (phen) 2 (qtpy)] 2 based on a PEDOT-PSS/Ag nanoparticles modified electrode. Int. J. Electrochem. Sci. 2013, 8, 11048-11057.

141. Dutse, S.W.; Yusof, N.A.; Ahmad, H.; Hussein, M.Z.; Zainal, Z. An electrochemical DNA biosensor for Ganoderma boninense pathogen of the oil palm utilizing a New ruthenium complex,[Ru (dppz) 2 (qtpy) $\mathrm{Cl}_{2}$. Int. J. Electrochem. Sci. 2012, 7, 8105-8115.

142. Mustafa, I.F.; Hussein, M.Z.; Saifullah, B.; Idris, A.S.; Hilmi, N.H.Z.; Fakurazi, S. Synthesis of (hexaconazole-zinc/aluminum-layered double hydroxide nanocomposite) fungicide nanodelivery system for controlling Ganoderma disease in oil palm. J. Agric. Food Chem. 2018, 66, 806-813. [CrossRef] [PubMed]

143. Mustafa, I.F.; Hussein, M.Z.; Seman, I.A.; Hilmi, N.H.Z.; Fakurazi, S. Synthesis of dazomet-zinc/aluminumlayered double hydroxide nanocomposite and its phytotoxicity effect on oil palm seed growth. ACS Sustain. Chem. Eng. 2018, 6, 16064-16072. [CrossRef]

144. Ariffin, D.; Idris, S. Investigation on the control of Ganoderma with dazomet. In Proceedings of the PORIM International Palm Oil Conference. Progress, Prospects Challenges Towards the 21st Century.(Agriculture), Kuala Lumpur, Malaysia, 20-25 September 1993. L-0218.

145. Maluin, F.N.; Hussein, M.Z.; Yusof, N.A.; Fakurazi, S.; Idris, A.S.; Hilmi, Z.; Hailini, N.; Jeffery Daim, L.D. Preparation of chitosan-hexaconazole nanoparticles as fungicide nanodelivery system for combating Ganoderma disease in oil palm. Molecules 2019, 24, 2498. [CrossRef] [PubMed]

146. Maluin, F.N.; Hussein, M.Z.; Yusof, N.A.; Fakurazi, S.; Idris, A.S.; Hilmi, N.H.Z.; Jeffery Daim, L.D. A potent antifungal agent for basal stem rot disease treatment in oil palms based on chitosan-dazomet nanoparticles. Int. J. Mol. Sci. 2019, 20, 2247. [CrossRef] [PubMed]

147. Maluin, F.N.; Hussein, M.Z.; Yusof, N.A.; Fakurazi, S.; Abu Seman, I.; Zainol Hilmi, N.H.; Jeffery Daim, L.D. Enhanced fungicidal efficacy on Ganoderma boninense by simultaneous co-delivery of hexaconazole and dazomet from their chitosan nanoparticles. RSC Adv. 2019, 9, 27083-27095. [CrossRef]

148. Azhari, M.A.; Putri, I.W.; Pratama, A.I.; Hidayah, R.E.; Ambarsari, L. Development of Trichodermin nanoemulsion based on medium chain triglycerides as antifungal of Ganoderma boninense in vitro. Curr. Biochem. 2019, 4, 2.

149. Lee, K.W.; bin Omar, D.; bt Abdan, K.; Wong, M.Y. physiochemical characterization of nanoemulsion formulation of phenazine and their antifungal efficacy against Ganoderma boninense PER71 in vitro. Res. J. Pharm. Biol. Chem. Sci. 2016, 7, 3056-3066.

(C) 2020 by the authors. Licensee MDPI, Basel, Switzerland. This article is an open access article distributed under the terms and conditions of the Creative Commons Attribution (CC BY) license (http://creativecommons.org/licenses/by/4.0/). 